\title{
KaJIAN NILAI BUDAYA TENTANG MITOS DAN PELESTARIAAN LINGKUNGAN pada masYaRAKAT BANGEUY KabUPATEN SUBANG
}

\author{
Oleh Endang Supriatna
}

Balai Pelestarian Sejarah dan Nilai Tradisional Bandung

J1. Cinambo No. 136 Ujungberung Bandung

Email: supriatnaraihan@ymail.com

\begin{abstract}
Abstrak
Kampung Banceuy terletak di Desa Sanca, Kecamatan Jalancagak, Kabupaten Subang. Masyarakat yang tinggal di Kampung Banceuy memiliki ciri kehidupan yang unik. Ciri khas masyarakat Banceuy di antaranya: mereka memiliki tokoh adat yang memimpin dan mengendalikan perilaku kepercayaan masyarakat setempat. Serta mereka masih memelihara nilai-nilai luhur dan tradisi upacara. Begitu banyak upacara yang masih mereka laksanakan, baik yang berkaitan dengan pertanian, daur hidup manusia, dan sistem religi. Banyak hal yang bisa dipetik dari pelaksanaan upacaraupacara tersebut, antara lain, nilai-nilai mitos dan ritual mendorong mereka menjalin hubungan timbal balik dengan lingkungan alam sekitar.
\end{abstract}

Kata kunci: Upacara tradisional, mitos, pelestarian lingkungan.

\section{Abstract}

The village of Banceuy lies in Desa (larger village) Sanca, Kecamatan (district) Jalancagak, Kabupaten (regency) Subang. The people there has a unique life, e.g. they have a chief who responsible as leader in controlling the behavior of the community member either in rituals or high-valued ancestral traditions. The rituals they have are, among others, ones that have something to do with agriculture, human life cycle and religious system. Those rituals make them maintain a good relationship with mother nature in term of preserving and conserving the environment.

Keywords: traditional ceremony, myths, environmental preservation 


\section{A. PENDAHULUAN}

Isu lingkungan hidup akan selalu aktual jika diperbincangkan, selain sangat erat dengan kehidupan manusia, cakupan permasalahan di dalamnya pun cukup luas. Bahkan, dewasa ini, permasalahan yang mencuat ke permukaan berkaitan dengan lingkungan hidup semakin kompleks. Hal itu diindikasikan dengan merebaknya berbagai permasalahan lingkungan hidup yang menjadi isu nasional maupun global.

Menelusuri berbagai faktor penyebab terjadinya sejumlah kasus lingkungan hidup ternyata cukup sulit. Modernisme dan kemajuan teknologi, di satu sisi, memang sangat berperan dalam pemenuhan kebutuhan manusia dan menunjang kehidupan manusia yang lebih baik. Pada sisi lain, pemanfaatan teknologi semakin memanjakan manusia. Akan tetapi, di balik itu semua ternyata harga yang harus dibayar sungguh amat mahal. Pemanfaatan kemajuan teknologi mendorong eksploitasi sumber daya alam yang semakin masif. Dari tahun ke tahun, eksploitasi sumber daya alam mengalami peningkatan, yang berujung pada semakin merosotnya kualitas daya dukung alam untuk menopang kebutuhan manusia.

Munculnya berbagai kasus lingkungan hidup merupakan indikasi yang memperlihatkan adanya kemerosotan kualitas hubungan timbal balik antara manusia dengan lingkungan alam. Melihat fenomena tersebut, betapa kepedulian manusia terhadap lingkungan hidup merupakan faktor penting dalam menjaga kelestarian alam. Pemeliharaan kelestarian alam akan turut menjaga kebutuhan manusia akan sumber daya alam.
Kampung Banceuy terletak di Desa Sanca, Kecamatan Jalancagak, Kabupaten Subang. Masyarakat yang tinggal di Kampung Banceuy memiliki ciri kehidupan yang unik. Ciri khas masyarakat Banceuy di antaranya: pertama, adanya tokoh adat yang memimpin dan mengendalikan perilaku kepercayaan masyarakat setempat. Kedua, masyarakat Kampung Banceuy masih memelihara nilai-nilai luhur dan tradisi upacara.

Begitu banyak upacara yang masih dilaksanakan oleh mereka, baik yang berkaitan dengan pertanian, daur hidup manusia, dan sistem religi. Banyak hal yang bisa dipetik dari pelaksanaan upacara-upacara tersebut, antara lain, hubungan timbal balik antara manusia dengan lingkungan alam sekitar, serta pola hubungan antara manusia (dalam hal ini masyarakat Banceuy) dengan lingkungannya bertitik tolak dari sistem keyakinan yang selama ini mereka yakini dan mereka lakukan sebagai filosofi hidup mereka.

Upacara Ngaruat Bumi, juga disebut Hajat Bumi, sebelumnya didahului oleh rangkaian upacara, seperti upacara hajat solokan, mapag cai, mitembeyan, netepkeun, nganyaran, hajat wawar, ngabangsar, dan kariaan. Prosesi upacara-upacara tersebut terkait dengan proses pertanian, khususnya budidaya padi. Padi bagi masyarakat Banceuy bersifat sakral dan segala proses menghasilkannya dipandang suci. Beragam upacara yang digelar menjadi spirit hidup warga yang mewarisi tradisi bercocok tanam padi, berkebun, dan beternak.

Agar penelitian ini tepat sasaran diperlukan satu perumusan masalah, yang dinyatakan dalam bentuk pertanyaan 
sebagaiberikut:(a)Apa yang menjadi latar belakang pelaksanaan upacara Ngaruat Bumi? (b) Bagaimana deskripsi Upacara Ngaruat Bumi secara keseluruhan? (c) Bagaimanakah mitos yang terdapat pada upacara Ngaruat Bumi? (d) Adakah kaitan antara kepercayaan terhadap mitos di sekitar upacara Ngaruat Bumi dengan pelestarian lingkungan?

Ada dua tujuan yang ingin dicapai dengan melaksanakan penelitian tentang Kajian Nilai Budaya tentang Mitos dan Pelestarian Lingkungan pada masyarakat Banceuy kabupaten Subang. Tujuan yang pertama adalah untuk mengetahui beberapa hal berikut ini (a) latar belakang upacara Ngaruat Bumi; (b) gambaran secara menyeluruh pelaksanaan upacara tersebut; (c) identifikasi nilai budaya tentang mitos yang terdapat pada Upacara Ngaruat Bumi; (d) makna mitos menurut interpretasi masyarakat pendukung upacara tersebut; (e) identifikasi nilai budaya yang terdapat dalam mitos, berdasarkan hasil interpretasi peneliti. Tujuan kedua, penelitian ini diharapkan dapat mendokumentasikan nilainilai budaya masyarakat pendukung upacara tersebut sehingga hasilnya turut memperkaya nilai-nilai budaya masyarakat luas secara keseluruhan.

Ruang lingkup penelitian ini meliputi dua hal, yakni ruang lingkup wilayah dan materi. Ruang lingkup wilayah penelitian ini adalah Kampung Banceuy yang berada di Desa Sanca, Kecamatan Jalan Cagak, Kabupaten Subang. Wilayah Banceuy dipilih sebagai tempat penelitian karena ditempati oleh masyarakat yang masih melaksanakan sejumlah upacara adat. Ruang lingkup materi penelitian ini meliputi gambaran umum daerah penelitian, yang di dalamnya menggambarkan lokasi dan keadaan alam, pola perkampungan, kependudukan, latar belakang sosial budaya; juga uraian berkenaan dengan upacara, bentuk mitos berikut maknanya, serta identifikasi nilai budaya yang berkaitan dengan pelestarian lingkungan masyarakat setempat.

Penelitian ini merupakan jenis penelitian yang bersifat deskripsi atau menggambarkan. Penelitian deskriptif ini bertujuan menggambarkan secara tepat sifat-sifat suatu gejala sosial, baik individu-individu, kelompok-kelompok, dan keadaan sosial tertentu. Oleh karena itu, pendekatan atau metode yang dipandang tepat untuk jenis penelitian deskriptif adalah pendekatan kualitatif.

Zulyani Hidayah (2006) menjelaskan, pendekatan kualitatif digunakan untuk memahami persoalan sosial atau budaya manusia berdasarkan pada suatu pengembangan gambaran yang kompleks dan holistis, dibangun dengan susunan kata, menyajikan pandangan detil dari informan dan dilaksanakan di lingkungan alamiahnya. Metode kualitatif juga dilaksanakan dalam situasi yang memungkinkan peneliti berinteraksi secara langsung dengan orang-orang yang diteliti, dalam upaya memperoleh data dari sumber pertama.

Teknik pengumpulan data yang digunakan di lapangan adalah observasi dan wawancara. Observasi dilakukan dengan maksud memperoleh data dengan pengamatan langsung di wilayah Kabupaten Subang. Data yang diperoleh selain menunjukkan kenyataan yang sewajarnya atau apa adanya, juga dapat melengkapi data yang tidak terungkap dalam wawancara.

Teknik wawancara yang digunakan merupakan cara penting dalam penelitian ini. Wawancara dimaksudkan guna 
memperoleh data secara langsung dari informan yang paling kompeten serta menjadi fokus penelitian ini. Dengan demikian, data mengenai pendapat, pandangan, dan pengetahuan, maupun mengenai kenyataan-kenyataan yang ada dan diketahui informan dapat terungkap secara lengkap dan dapat dipercaya. Wawancara yang dilakukan merupakan wawancara mendalam (depth-interview) dengan mempergunakan pedoman wawancara.

\section{B. HASIL DAN BAHASAN}

\section{Selintas Kampung Banceuy}

\section{a. Lokasi dan Keadaan Alam}

Kampung Banceuy termasuk ke dalam wilayah administratif Desa Sanca, Kecamatan Jalan Cagak, Kabupaten Subang, Provinsi Jawa Barat. Secara geografis. Kampung Banceuy berada pada ketinggian 770 meter di atas permukaan laut. Suhu rata-rata di wilayah tersebut berada pada kisaran $26-28$ derajat celcius. Sementara itu curah hujan setiap tahunnya adalah $2.700 \mathrm{~mm}$. Kondisi topografi wilayah ini terdiri atas dataran dan perbukitan atau pegunungan.

Luas wilayah Kampung Banceuy mencapai 157 hektar, 47 hektar dari luas tersebut adalah hutan, 78 hektas berupa sawah, 20 hektar kebun, dan 12 hektar merupakan lahan hunian penduduk. Hutan, kebun, dan sawah merupakan sumber daya alam yang ada di Kampung Banceuy. Selain itu, di wilayah kampung ini terdapat sungai kecil yang dinamakan Solokan Ito, Solokan Cipadaringan, dan air terjun yang diberi nama Curug Bentang. Sampai saat ini Curug Bentang menjadi salah satu objek wisata di Kampung Banceuy.
Letak Kampung Banceuy di Kecamatan Jalan Cagak berbatasan dengan kampung lainnya adalah sebagai berikut: sebelah utara berbatasan dengan sawah Tegal Malaka; sebelah selatan berbatasan denganSolokan Cipadaringan; sebelah barat berbatasan dengan Solokan Cipatat; dan di sebelah timur berbatasan dengan Sungai Cipunagara.

Akses menuju Kampung Banceuy dapat ditempuh melalui beberapa alternatif, yakni: Pertama, melalui Kampung Palasari, Cinungku, Cicalung, dan tiba di Kampung Banceuy. Perjalanan tersebut memerlukan waktu tempuh sekitar 25 menit dengan alat kendaraan sepeda motor (ojeg). Kedua, melalui Jalan Cagak, Kasomalang, Sanca, dan sampai di Kampung Banceuy. Waktu tempuh rute tersebut sekitar 60 menit yang dapat ditempuh dengan kendaraan roda empat maupun ojeg. Ketiga melalui Ciater, Nagrak, Cibitung, Cicalung, dan tiba di Kampung Banceuy. Waktu yang diperlukan untuk menempuh rute ini sekitar 30 menit dengan kendaraan ojeg.

Jarak yang harus ditempuh dari Kampung Banceuy ke Kecamatan Jalan Cagak adalah 7-8 kilometer, dengan waktu tempuh selama setengah jam; jarak ke Kabupaten Subang sejauh 23 kilometer dengan waktu tempuh yang diperlukan sekitar 2 jam; dan jarak Kampung Banceuy ke ibukota Provinsi Jawa Barat atau Kota Bandung kurang lebih sekitar 50 kilometer dengan waktu tempuh 2 jam; jarak ke ibukota negara atau Jakarta sekitar 186 kilometer, dengan waktu tempuh sekitar 3,5 jam. Sementara itu, jarak Kampung Banceuy menuju pusat fasilitas kota terdekat seperti fasilitas ekonomi (pasar) dan kesehatan (puskesmas) yang terdapat di Kampung Kasomalang, sekitar 45 menit. 


\section{b. Pola Perkampungan}

Nama kampung yang sekarang dikenal dengan sebutan Kampung Banceuy dahulu disebut Kampung Negla. Mengapa berubah disebut Banceuy? Ternyata ada riwayatnya. Konon ke Kampung Negla pada waktu dulu datang 7 keluarga. Mereka membangun rumah dan menetap di sana. Kampung yang mereka tinggali itu suatu waktu diterjang bencana berupa angin topan yang menyebabkan rumah-rumah mereka hancur. Mereka pun mulai membangun rumah kembali. Ketujuh keluarga itu pun berkumpul untuk membicarakan agar kampung mereka dapat terhindar dari bencana serupa di kemudian hari. Mulailah mereka berkumpul dan berunding untuk mencari jalan keluarnya. Untuk memutuskan hal itu, mereka mengundang seorang paranormal. Ternyata ia menyarankan beberapa hal untuk keselamatan dan kedamaian kampung tersebut. Pertama, kampung harus dipimpin oleh keturunan Aki Ito. Kedua, warga penduduk harus melaksanakan ruwatan bumi. Ketiga, kampung tersebut harus diganti namanya. Untuk memberi nama baru kampung mereka, mereka memberi nama Banceuy, yang diambil dari kata ngabanceuy yang berarti musyawarah. Mereka (para pendahulu kampung itu) melakukan musyawarah atau ngabanceuy untuk mencari keselamatan dan kedamaian kampung tersebut. Sejak saat itu, di Kampung Banceuy selalu diselenggarakan Upacara Ngaruat Bumi.

Kampung Banceuy juga sering disebut Nagara Banceuy, yang lahir dari keteguhan warga Banceuy dalam memelihara dan melaksanakan adat istiadat yang diwarisi dari para leluhur. Pengertian nagara dalam hal ini adalah sebuah wilayah yang dengan ketat dipagari oleh adat istiadat.

Pola perkampungan Banceuy tergolong pola perkampungan yang linier, ditandai dengan adanya jalan raya atau jalan kampung yang memanjang. Rumah-rumah tinggal warga kampung tersebut berada di sepanjang jalan kampung. Unsur-unsur yang melengkapi kampung seperti sarana ibadah, sarana pendidikan, sarana untuk berusaha, dan lapangan olah raga.

Rumah-rumah di Kampung Banceuy terdiri atas 193 rumah permanen dan 60 rumah nonpermanen. Ukuran rumah bervariasi antara $5 \times 7,6 \times 9$, dan $9 \times 12$ meter. Yang paling banyak rumah berukuran 6x9 meter. Sepintas terlihat seperti tidak ada tanda yang khas. Padahal ada aturan-aturan yang mengatur tata letak atau tata ruang rumah dan unsurunsur rumah.

Pertama, aturan letak rumah sangat berkaitan dengan hubungankekeluargaan. Seorang anak tidak boleh membangun rumah di sebelah timur orang tuanya; seorang adik juga dilarang mendirikan rumah di sebelah timur kakaknya. Dalam istilah mereka, perbuatan seperti itu disebut ngalangkangan, hal tersebut dilarang menurut keyakinan warga Kampung Banceuy.

Kedua, aturan letak pintu erat kaitannya dengan rezeki. Pintu depan rumah (pintu utama) dan pintu belakang harus menghadap ke selatan dan utara. Kedua pintu tidak boleh sejajar atau langsung, melainkan harus dihubungkan dengan pintu tengah yang posisinya tidak sejajar dengan kedua pintu tadi, atau dikenal dengan istilah nyegog. Dasar filosofisnya agar rezeki yang didapat keluarga tersebut tidak cepat habis atau akan nyangkut di rumah keluarga itu. 
Ketiga, aturan penempatan goah berhubungan erat dengan perhitungan hari baik yang berkenaan dengan hari kelahiran pemilik rumah. Jika lahir hari Selasa, Kamis, dan Sabtu, maka goah harus berada antara timur dan utara, jika lahir Rabu, Senin, dan Sabtu, goah harus berada antara sebelah selatan dan barat. Selain aturan tadi, goah pun harus sejajar dengan kamar-kamar tidur.

Tata ruang rumah di Kampung Banceuy harus disesuaikan dengan beberapa unsur berikut: teras rumah, ruang tamu, ruang keluarga, kamar tidur, goah, dan dapur. Ada yang unik berkenaan dengan langi-langit rumah. Umumnya pada lagit-langit rumah mereka ada bagian yang diberi (berlapiskan) papan dan agak terbuka. Letak bagian itu biasanya ada di dapur.

Fungsi langit-langit seperti dijelaskan ini erat kaitannya dengan pelaksanaan hajatan. Dalam setiap hajatan, senantiasa ada acara netepkeun atau ngadiukkeun, yakni memasukkan (menyimpan) makanan seperti kue-kue ke langit-langit rumah. Pada saat seperti itu, tempat tersebut akan ditunggui seseorang yang disebut candoli kueh. Sementara itu, dapur rumah di Banceuy masih terlihat tradisional, dengan perlengkapan yang paling utama berupa tungku atau hawu. Sekalipun ada kompor minyak tanah, mereka tetap menggunakan hawu untuk keperluan memasak sehari-hari. Hal itu dilakukan untuk memanfaatkan kayu bakar yang ada di wilayah sekitar.

Kamar mandi umumnya berada di luar rumah dan terbuka. Selain itu, di belakang rumah biasanya ada tempat untukmenyimpankayubakar dankandang ternak seperti ayam, kambing, domba, atau sapi. Jika tidak memungkinkan menyimpan sapi di belakang rumah, mereka akan menempatkannya di sekitar tegalan atau padang rumput, yang juga menjadi tempat untuk menggembalakan ternak. Cukup banyak kandang sapi milik warga Banceuy di tempat itu.

Umumnya, di depan rumah penduduk masih tersisa lahan untuk halaman, yang digunakan untuk menanam pohon atau kebutuhan lainnya. Luas halaman yang terdapat di setiap rumah berbeda, mulai yang sempit hingga yang luas. Antarrumah penduduk diberi batas pagar besi, tanaman hidup, tembok, atau bilah-bilah bambu.

Tidak jauh dari rumah penduduk, banyak ditemukan saung lisung. Sebagian ibu di sana memang masih menumbuk padi di lesung. Tempat tersebut juga kerap dijadikan tempat pelaksanaan sejumlah upacara adat, tepatnya untuk acara tutunggulan. Yang dimaksud tutunggulan adalah memainkan alu pada lesung sehingga suara tumbukan keduanya berirama musik tertentu. Di sana juga terdapat satu tempat penggilingan padi atau heuleur.

Sarana umum yang terdapat di dalam perkampungan Banceuy salah satunya adalah sarana pendidikan. Di sana hanya ada satu sekolah dasar dan madrasah tsanawiyah. Kalau ingin melanjutkan ke SMP negeri atau ke SMA, mereka harus pergi ke Jalan Cagak sejauh 7-8 kilometer mengendarai ojeg dengan ongkos Rp. 5.000,00 sekali jalan. Sekolah dasar satu-satunya di Kampung Banceuy yaitu Sekolah Dasar Karang Madu, dan madrasah tanawiyah yang dikelola oleh sebuah lembaga swasta. Merapat dengan bangunan SD bagian depan, terdapat panggung tembok permanen. Tempat tersebut digunakan untuk upacara-upacara tradisional, seperti Ngaruat Bumi. 
Masih di depan bangunan SD, hanya terpisah oleh jalan, terdapat bale pertemuan yang berdiri sejak tahun 1965 . Tempattersebut digunakanuntukberbagai aktivitas yang bersifat musyawarah dan upacara. Di bale pertemuan ditempatkan satu alat komunikasi massa yang masih tradisional, yakni kohkol. Alat tersebut digunakan untuk memberitahukan adanya peristiwa-peristiwa tertentu kepada masyarakat, seperti kebakaran, ada bahaya, atau kematian. Konon irama yang muncul akan berbeda utuk setiap peristiwa sehingga dapat dipahami oleh masyarakat.

Sarana peribadatan yang ada di Kampung Banceuy di antaranya 1 bangunan masjid jami dan ada 4 - 5 langgar atau masjid kecil. Sarana olah raga yang tersedia adalah lapangan sepakbola, yang sekaligus juga menjadi tempat mengembala ternak.

Pengelolaan sanitasi lingkungan tercermin pula dalam pola perkampungan Banceuy. Sampah rumah tangga biasanya dibakar atau dikubur dalam tanah. Air bersih diperoleh dari pegunungan dan disalurkan melalui bak-bak penampungan. Penyediaan dan pengelolaan air bersih dilakukan secara gotongroyong dan swadaya masyarakat. Di sana juga terdapat MCK umum yang diperuntukkan bagi keluarga yang kurang mampu.

Selain wujud fisik seperti itu, masyarakat juga mengadakan upacara ritual untuk membersihkan lingkungan dan manusia dari berbagai penyakit. Upacara tersebut dinamakan hajat lingkungan atau hajat wawar. dilakukan secara rutin setiap tiga bulan sekali. Upacara ini dilakukan sebagai tindakan preventif, atau jika ada situasi darurat, seperti ada wabah diare, sakit panas, atau ada wabah penyakit ngeluk atau tetelo pada ternak mereka (biasanya unggas).

Sarana pelayanan kesehatan bagi warga Banceuy ternyata letaknya cukup jauh dari kampung mereka, yaitu di Jalan Cagak (puskesmas tingkat desa), yang berjarak 7-8 kilometer. Tenaga kesehatan yang ada di wilayah itu adalah seorang bidan dan dua orang mantri kesehatan. Untuk keperluan kesehatan, masyarakat Banceuy lebih banyak menggunakan obat tradisional yang mereka usahakan sendiri. Obat-obat medis yang dijual bebas dijual pula di warung yang dekat dengan kampung mereka, tetapi kondisinya sangat terbatas.

\section{c. Sistem Religi}

Satu hal yang penting dalam kehidupan masyarakat Kampung Banceuy adalah terjaganya hubungan yang erat dengan para leluhur. Dalam pandangan mereka, para leluhur adalah para pendahulu yang membuka kawasan tersebut yang kini disebut Kampung Banceuy. Kepercayaan kepada para leluhur tercermin dari berbagai bentuk aturan adat dan ritual yang diformulasikan dalam bentuk upacara-upacara adat.

Seluruh warga kampung Banceuy mengaku beragama Islam. Namun demikian, keyakinan kepada para leluhur bersamaan dijalankan secara ketat melalui berbagai kegiatan upacara adat. Aktivitas keagamaan sehari-hari diwujudkan dalam kegiatan ibadah harian seperti shalat, pengajian untuk anakanak, ibu-ibu maupun laki-laki dewasa. Pengajian untuk anak-anak dilaksanakan setiap Magrib dan Subuh. Mereka belajar membaca al-Quran atau mengaji, belajar praktik ibadah, dan pengetahuan agama lainnya. Pengajian ibu-ibu dilaksanakan seminggu sekali, yaitu pada setiap hari 
Jumat setelah Shalat Ashar. Pengajian untuk kaum bapak-bapak dilaksanakan setelah Shalat Subuh.

Mereka juga menyelenggarakan peringatan hari-hari besar Islam seperti Maulud Nabi, Rajaban, Idul Fitri, dan Idul Adha. Dalam perayaan hari besar, selain diadakan ceramah keagamaan, juga mereka merayakan hajatan secara tradisional. Aktivitas keagamaan seperti itu berada di bawah bimbingan pemimpin keagamaan atau kyai yang ada di kampung mereka.

Kepercayaan masyakat Banceuy terhadap warisan dari leluhurnya adalah pandangan dan keyakinan mereka tentang alam, manusia, serta kehidupan dan kematian. Keyakinan mereka tentang alam atau kosmologi, yaitu keyakinan bahwa alam ini terdiri atas alam dunia (alam nyata) dan alam gaib. Alam dunia diisi oleh makhluk hidup, seperti manusia, hewan, dan tumbuh-tumbuhan, atau benda-benda nyata yang dapat dikenali melalui panca indera. Alam gaib dihuni oleh makhluk halus berupa roh para karuhun, jin, syetan, hantu atau dedemit.

Menurut keyakinan mereka, roh suci selain menguasai tempat-tempat tertentu, juga berhubungan erat dengan manusia. Keyakinan kepada bendabenda yang dianggap berhubungan sangat erat dengan manusia. Padi, misalnya, menurut keyakinan mereka adalah penjelmaan dari Dewi Sri; Pohon Kawung dipercaya sebagai jelmaan dari Nyi Pohaci Hideung; Nabi Hidir atau disebut juga Batara Banyu yaitu roh suci yang menguasai air; dan Batara Susuk Tunggal diyakini sebagai roh suci yang menguasai solokan (saluran air).

Mereka meyakini bahwa manusia bisa berhubungan dengan makhluk- makhluk halus, bahkan para roh suci ini dapat dicaluk (dipanggil) untuk dimintai pertolongan. Demikiaan pula, mereka percaya bahwa roh para karuhun (leluhur) dapat mendatangkan bencana atau malapetaka bagi warga masyarakat. Oleh karena itu, masyarakat Banceuy senantiasa memelihara hubungan dengan roh para leluhur melalui berbagai upacara adat atau persembahan

Konsep masyarakat Banceuy tentang manusia, di antaranya, bahwa jasad manusia terdiri atas empat sir (unsur), yakni sir bumi, sir geni, sir angin, dan sir banyu/air (unsur tanah, api, angin, dan air). Keempat sir ini membentuk manusia dengan sifat dan tabiatnya. Selain itu, manusia pun dapat dipengaruhi oleh empat jiwa, yaitu jiwa hewan, setan, jiwa roban (pohonpohonan), dan jiwa manusia sejati. Tiga jiwa yang disebut pertama merupakan jiwa pengganggu yang selalu berusaha menguasai jiwa manusia pada jalan kesesatan dan kecelakaan. Adapun jiwa manusia sejati merupakan penangkal segala godaan ketiga jiwa tersebut. Untuk memperkuat jiwa manusia sejati dapat dicapai melalui jalan eling (ingat). Manusia harus menyadari kodrat dan fungsi hidup di dunia, yaitu hidup selaras dengan lingkungan alam sekitar, tidak boleh mengumbar nafsu.

Konsep masyarakat Banceuy tentang kematian adalah terlepasnya sukma (roh) dari raga (badan, jasad). Selama 40 hari, roh orang yang sudah berpisah dengan badan, masih berkeliaran di sekitar tempat tinggalnya. Oleh karena itu, sampai 40 hari setelah peristiwa kematian, maka anak atau kerabatnya harus melakukan tahlilan dan menyediakan sesajen untuk roh tersebut. Setelah 40 hari, roh akan dijemput oleh 
roh para karuhunnya (ibu, bapak, atau para pendahulu). Selanjutnya roh mereka (yang telah meninggal) berkumpul dengan roh-roh lainnya di alam suci atau alam gaib, sambil menunggu hari kiamat. Selama berada di alam gaib, mereka mengawasi perilaku manusia yang masih hidup. Roh para pendahulunya masih bisa berkomunikasi dan bahkan bisa dicaluk (diundang) oleh yang masih hidup.

Pada bulan Ramadhan (bulan Puasa), roh-roh tadi dibebaskan untuk mengunjungi sanak keluarganya. Oleh karena itu, satu hari menjelang datangnya bulan Ramadhan, warga masyarakat setempat menyediakan sesajen untuk mapag (menyambut) kedatangan roh tersebut. Begitu pula pada akhir Ramadhan, disediakan sesajen untuk mekelan (membekali) roh yang akan kembali ke alam suci.

Dari sistem kepercayaan tersebut lahirlah berbagai jenis upacara tradisional yang masih dilaksanakan oleh masyarakat Banceuy. Adapun upacara tradisional yang berkaitan dengan aktivitas pertanian adalah sebagai berikut:

- Upacara Mapag Cai, yakni menyambut datangnya aliran air ke Kampung Banceuy. Tempat upacaranya di tanggul Cipadaringan, sungai yang paling besar di kampung tersebut dan merupakan sungai yang amat vital bagi masyarakat Banceuy. Waktu pelaksanaannya adalah pada bulan kesepuluh, bertepatan dengan mengalirnya air ke wilayah sawah Kampung Banceuy.

- Upacara Hajat Solokan, yaitu upacara meminta berkah kepada Tuhan, karuhun, dan penghuni solokan (sungai) tersebut agar air sungai tersebut senantiasa lancar.
Upacara tersebut dilaksanakan di dua tempat, yakni di Solokan Eyang Ito dan di Solokan Cipadaringan. Untuk keperluan upacara tersebut harus disediakan hewan sembelihan, yakni dua ekor domba yang akan disembelih pada waktu upacara di masing-masing sungai tersebut. Peserta upacara adalah masyarakat yang lahan pertanian mereka dilalui oleh kedua sungai tersebut. Dengan demikian, masyarakat akan menyediakan di tiap solokan seekor domba secara patungan. Darah segar dari masing-masing hewan tersebut ditumpahkan di kedua sungai disebut. Warga masyarakat yang memiliki lahan pertanian yang dialiri sungai tersebut secara otomatis akan menjadi peserta upacara Hajat Solokan.

- Upacara Ngaruwat Bumi merupakan upacara adat pertanian yang paling penting bagi masyarakat Banceuy. Upacara ini dilaksanakan setelah panen. Tujuannya adalah untuk mengungkapkan rasa syukur warga Banceuy terhadap Tuhan, serta para karuhun atas hasil panen yang mereka dapatkan pada tahun tersebut. Selain itu, pada musim tanam tahun depannya, mereka berharap diberi kesuburan tanah dan peningkatan hasil panen.

- Upacara Netepkeun yakni upacara ritual menyimpan beras di dalam tempat penyimpanan beras atau goah.

- Upacara Nganyaran yakni upacara mengeluarkan padi yang pertama kali dari goah.

\section{d. Sistem Kemasyarakatan}

Seperti telah disinggung di atas, masyarakat Kampung Banceuy termasuk 
ke dalam kategori masyarakat adat. Hal itu dicirikan, salah satunya dengan adanya tokoh adat yang dijadikan panutan oleh masyarakat setempat. Tokoh atau ketua adat tersebut dijadikan sesepuh serta disapa dengan panggilan "Abah", serta menempati posisi yang sangat penting dalam struktur masyarakatnya. Semua aktivitas masyarakat yang bersifat adatistiadat hampir pasti melibatkan Abah. Ia pun memutuskan semua perkara yang bertalian dengan aturan adat. Warga masyarakat Banceuy sangat menghormati sesepuh adat mereka.

Aturan adat menentukan bahwa seorang ketua adat atau sesepuh adat haruslah seorang laki-laki. Ketua adat dibantu oleh sekelompok orang (laki-laki) yang dianggap para pinisepuh. Sebutan pinisepuh di masyarakat Banceuy disebut "Aki". Mereka adalah tangan kanan Abah dan memiliki tugas khusus dalam setiap penyelenggaraan upacara adat.

Hak pewarisan jabatan adat pada masyarakat Banceuy jatuh pada anak lakilaki tertua. Ketua adat yang tidak memiliki keturunan atau ahli waris laki-laki dalam istilah setempat disebut tumpur. Jika hal seperti itu menimpa seorang ketua adat, maka jabatan adat akan dipilih dari keturunan para sesepuh adat pembantu Abah. Meskipun demikian, tetap saja ada syaratnya, yaitu laki-laki dan telah menerima wangsit. Abah (ketua adat)-lah pada akhirnya menentukan penerusnya yang telah menerima wangsit.

Pinisepuh pertama (saat ini dijabat oleh Aki Suta) mempunyai tugas khusus, yaitu memimpin upacara Ngalawar. Pinisepuh kedua (saat ini dijabat oleh Aki Ruhendi) mempunyai tugas sebagai mediator antara Abah dengan warga masyarakat. Pinisepuh ketiga (saat ini Aki Arma) memiliki tugas khusus mendampingi Abah dalam setiap peristiwa adat, serta mewakili Abah bilamana Abah berhalangan. Dengan demikian, jika digambarkan dalam skema, adalah sebagai berikut:

\section{Sesepuh Adat/Abah $\downarrow$ \\ Para Pinisepuh \\ $\downarrow$ \\ Juru Kunci makam keramat $\downarrow$ \\ Warga Masyarakat Banceuy}

Skema di atas memberi gambaran bahwa Sesepuh Adat menempati kedudukan paling tinggi. Selanjutnya, Sesepuh Adat memimpin para Pini Sepuh, Juru Kunci makam, dan paling bawah adalah warga masyarakat. Skema struktur masyarakat juga mencerminkan adanya pelapisan masyarakat (social stratification) di Kampung Banceuy. Pelapisan masyarakat erat kaitannya dengan jenjang penghormatan warga masyarakat kepada orang di atasnya, dan seterusnya hingga ke tingkat paling tinggi, yaitu Sesepuh Adat.

Skema di atas tidak selalu menggambarkan tingkatan orang kaya di Kampung Banceuy. Keberadaan orang kaya biasanya dilihat dari kepemilikan bangunan rumah serta lahan pertanian yang paling luas. Tingkatan selanjutnya ditempati oleh orang yang paling banyak memiliki hewan ternak seperti sapi, domba/kambing. Kemudian ditempati oleh para bandar atau tengkulak sayuran yang menampung hasil sayuran dari kampung danmemasarkankembalikeluar wilayah kampung. Masyarakat Banceuy pun sangat menghormati orang yang mereka anggap memiliki pendidikan yang cukup tinggi serta orang yang memiliki 
jabatan kedinasan tertentu. Seperti seorang guru, di masyarakat Banceuy cukup dihormati oleh kebanyakan warga masyarakat biasa.

Namun demikian pelapisan masyarakat tidak menyebabkan masyarakat Banceuy terkotak-kotak atau kaku dalam pergaulan sehari-hari. Mereka lebih didominasi oleh aturan adat warisan leluhur mereka. Kontrol sosial berada di tangan Sesepuh Adat. Kontrol sosial masih berlaku, hal itu tercermin dengan masih dipatuhinya pantangan atau larangan adat. Masih dalam konteks menjaga keteraturan sosial, mereka juga mematuhi aturan-aturan yang datang dari pemerintah, seperti aturan yang datang dari camat, lurah, maupun dari RT.

Keteraturan yang menonjol dalam masyarakat adalah kerja sama. Nilai-nilai yang menjalin kerja sama tersebut adalah gotong royong dan tolong-menolong. Kehidupan yang saling menolong hampir mewarnai seluruh aspek kehidupan masyarakat.

\section{Nilai Mitos dan Upacara Tradisional Masyarakat Banceuy}

Salah satu unsur budaya yang sifatnya universal, dan terdapat pada hampir semua kebudayaan suku-suku bangsa di Indonesia adalah upacara tradisional. Menurut Budhisantoso, (1990: 7), upacara tradisional adalah tingkah laku resmi yang dibakukan untuk peristiwa-peristiwa yang tidak ditujukan pada kegiatan teknis seharihari, tetapi mempunyai kaitan dengan kepercayaan akan adanya kekuatan di luar kemampuan manusia atau kekuatan supernatural, seperti roh nenek moyang pendiri desa, roh leluhur yang dianggap masih memberikan perlindungan kepada keturunannya, dan sebagainya.
Upacara Ngaruat Bumi pada masyarakat Banceuy Kabupaten Subang telah berumur ratusan tahun. Namun, seperti Seren Taun di Ciptagelar, Kabupaten Sukabumi, atau di Cigugur, Kabupaten Kuningan, kesakralannya sebagai tradisi masyarakat agraris tetap terasa. Seren Taun dan Ngaruat Bumi adalah ungkapan syukur atas hasil yang diperoleh dari bumi, pengharapan setahun ke depan, serta penghormatan kepada leluhur. Ruat dalam bahasa Sunda berarti mengumpulkan dan merawat. Yang dikumpulkan dan dirawat adalah masyarakat dan hasil buminya.

Ruwatan Bumi, juga disebut Hajat Bumi, menggenapi rangkaian upacara yang digelar sebelumnya, seperti Upacara Hajat Solokan, Mapag Cai, Mitembeyan, Netepkeun, Nganyaran, Hajat Wawar, Ngabangsar, dan Kariaan. Mayoritas di antaranya terkait dengan proses pertanian, khususnya budidaya padi.

Dalam tradisi Ruwatan Bumi, padi memiliki tempat istimewa. Padi atau beras, dalam keyakinan masyarakat setempat, tidak hanya sebagai bahan pangan. Padi diyakini bermula dari aktivitas Dewa-Dewi sehingga bersifat sakral dan segala proses menghasilkannya dipandang suci.

Oleh karena itu, warga biasanya melakukan upacara atau ritual sebelum memasuki fase tertentu penanaman padi dan penanganannya setelah panen. Mapag Cai, misalnya, dilakukan sebelum menyemai benih dan mengolah sawah. Menjelang tanam atau panen, warga melaksanakan mitembeyan. Adapun ritual netepkeun dilakukan saat pertama kali menyimpan beras ke dalam goah (tempat penyimpanan beras) juga ritual nganyaran saat pertama mengeluarkan beras dari goah. Yang membedakan ritual 
satu dan lainnya adalah ikrar alias isi doa yang dipanjatkan pemimpin upacara.

Berbeda dengan di Cigugur atau Ciptagelar yang kegiatannya dipusatkan di tempat pemangku adat tertinggi, Ruwatan Bumi di Subang dilaksanakan tersebar di setiap kampung. Upacara dipimpin oleh sesepuh adat (sebutan bagi pemimpin adat di Kampung Banceuy) serta juru kunci atau kuncen (sebutan di luar Banceuy) masing-masing kampung.

Kecuali warga adat Kampung Banceuy di Desa Sanca yang melaksanakan ruwatan pada akhir Rayagung — bulan terakhir dalam sistem penanggalanSunda - mayoritaskampung lainnya melaksanakan ruwatan pada bulan Muharam, bulan pertama sistem penanggalan Hijriah. Sesepuh adat atau kuncen biasanya menentukan tanggal pelaksanaan berdasarkan keyakinan akan "hari baik" bagi kampungnya.

Kampung-kampung yang rutin menggelar hajat tersebar di wilayah Subang bagian selatan, khususnya di Kecamatan Ciater, seperti Desa Palasari, Ciater, Nagrak, Cibeusi, Cisaat, Cibitung, dan Sanca. Berada di ketinggian $770 \mathrm{~m}$ di atas permukaan laut atau lebih serta suhu $18^{\circ}-32^{\circ}$ Celsius, desa-desa itu jaraknya 23-30 km dari pusat kota Subang atau 32 $\mathrm{km}$ dari Kota Bandung.

Awal 1431 Hijriah ini-antara pertengahan Desember 2009 hingga pertengahan Januari 2010-adalah hari-hari pelaksanaan Ngaruat Bumi di Kabupaten Subang. Upacara Hajat Bumi di Desa Cibeusi terhitung paling tua dibandingkan dengan kampung/desa lain. Menurut Eming, kuncen di Kampung Peuntas, Desa Cibeusi, perayaan tahun ini merupakan yang ke-483 karena berdasarkan cerita turun-temurun dari leluhur, Hajat Bumi telah dilaksanakan di Cibeusi sejak tahun 1527 Masehi.

Prosesi Ngaruat Bumi berlangsung lebih dari sebulan, mulai dari dadahut (perencanaan) hingga pentas hiburan sebagai puncak acara. Diawali dengan pentas seni Gembyung buhun pada malam menjelang hari pelaksanaan, prosesi dilanjutkan dengan ritual potong padi, numbal dan menyimpan sesaji, selamatan, arak-arakan, dan berziarah ke makam leluhur sejak pagi hingga siang.

Pentas seni Gembyung, potong padi, numbal, dan selamatan menjadi prosesi wajib pada Ruwatan Bumi. Akibat keterbatasan dana, warga sebagian kampung menggelar ruwatan secara sederhana. Mereka hanya melaksanakan prosesi wajib dan tanpa panggung, arakarakan, atau hiburan.

Menurut Ketua Dewan Kesenian Kabupaten Subang, Wawan Herawan, seni dan budaya yang berkembang di Subang Selatan sangat lekat dengan tradisi masyarakat agraris. Beragam upacara yang digelar menjadi spirit hidup warga yang mewarisi tradisi bercocok tanam padi, berkebun, dan beternak.

Lekatnya tradisi juga mendasari sebagian petani, terutama di Desa Cibeusi, bertahan dengan padi-padi varietas lokal, seperti geulis mandi, pare hideung, rogol, sarikuning, marahmay, ketan bodas, dan ketan hideung. Mereka percaya padi-padi buhun (tradisi) warisan leluhur itu membawa berkah. Keberkahan itu tecermin dari hasil panen yang mencukupi kebutuhan pangan keluarga. Petani juga tak perlu membeli benih atau beras di pasar.

Sayangnya, jumlah petani yang bertahan dengan padi-padi buhun terus berkurang. Selain kalah produktivitas (60-70 persen dari produktivitas varietas 
unggul baru), umur padi-padi buhun itu lebih lama, yaitu 6-7 bulan atau lebih lama ketimbang varietas unggul ciherang dan $I R$ yang berumur kurang dari 4 bulan (tepatnya 100-120 hari). Pergeseran varietas padi dikhawatirkan mengganggu "kalender budaya" yang selama ini sejalan dengan jadwal tanam padi buhun.

\section{a. Mitos dan Pelestarian Lingkungan}

Istilah mitos erat kaitannya dengan masalah keyakinan atau sistem kepercayaan masyarakat dan dalam aktualisasi dari kepercayaan adalah apa yang disebut ibadat. Senada juga dengan apa yang ada dalam makalah Usman Pelly, yang mengartikan ibadat sebagai bagian dari tingkah laku religius yang aktif dan bisa ditaati. Bentuknya, bisa berupa mantra, ucapan-ucapan formal tertentu, samadi, nyanyian, doa, pemujaan, puasa, tarian, mencuci, membaca, memakai pakaian khusus, menyembelih atau melakukan korban.

Mitos menjadi bagian dari sistem kepercayaan masyarakat. Sistem kepercayaan yang dimiliki suatu masyarakat tentu akan berpengaruh pula pada pola pikir dan tingkah laku yang nantinya berujung pada caracara pengelolaan lingkungan. Dalam penciptaan peradaban manusia, menurut keyakinan masyarakat Banceuy, tidak lepas dari mitos dan alam.

Terlepas dari benar tidaknya, mitos, seperti telah dikemukakan di atas, memberikan pelajaran kepada masyarakat luas bagaimana sikap manusia terhadap alam. Meskipun dalam cerita tersebut terdapat unsur gaib, namun masyarakat terutama yang bersifat tradisional relatif dapat mengikuti perintah yang secara tersirat dalam cerita tersebut.
Bentuk-bentuk penghormatan kepada gunung dan hutan sebagai ruang yang diyakini sebagai tempat yang "berpenghuni" dalam arti terdapat kekuatan gaib atau istilahnya angker, ternyata menciptakan cara berperilaku yang tidak jauh dengan prinsip konservasi. Dalam prinsip konservasi yang dibutuhkan adalah rasa saling menghormati dan menjaga alam. Masyarakat cenderung akan berpikir ulang jika melakukan kegiatan di tempattempat yang dianggap angker. Mereka akan menjaga dan menghormati tempattempat tersebut. Meskipun bentuk dari penghormatan tersebut seringkali berupa ritual-ritual tertentu, namun dalam hal ini mampu menciptakan sikap bijaksana untuk menghargai alam. Suatu tempat yang dianggap angker membuat aktivitas manusia jarang dilakukan di tempat tersebut. Hal itu justru dapat menjaga keseimbangan ekosistem karena kurangnya aktivitas manusia.

Mitos juga berlaku pada hewanhewan tertentu yang dianggap keramat, seperti ular, kucing, burung gagak, burung hantu, dan hewan lainnya. Dengan adanya mitos ini kelangsungan hidup hewan tersebut lebih terjamin, karena masyarakat menganggap keramat hewan ini. Mengingat satwa adalah bagian dari jaringan ekosistem yang turut pula memainkan perannya dalam menjaga keseimbangan ekosistem. Sebagai contoh mitos Dewi Sri yang menjelma sebagai ular sawah. Mitos ini ada jauh sebelum ilmu pengetahuan tentang lingkungan berkembang. Masyarakat petani mengeramatkan ular sawah karena dianggap sebagai jelmaan dari Dewi Sri yang membawa keberkahan dan kesuburan sawah. Lewat kacamata ilmu pengetahuan adanya ular sawah 
tersebut akan membantu petani dalam mengendalikan hama terutama tikus sawah. Kotorannya juga dapat menjadi pupuk yang menjaga kesuburan tanah.

Masyarakat Kampung Banceuy sangat mengutamakan sesajen pada tiap tahap upacara tradisional. Sesajen meupakan seperangkat persembahan yang digunakan untuk menghormati penunggu tempat-tempat tertentu, seperti pohon besar, muara sungai, dan lain-lain. Selokan (Cikahuripan dan Cipadaringan) sebagai sarana mengalirnya air, unsur yang amat vital dalam bertani, diberi sesajen agar orang (masyarakat) menjaga sungai atau selokan tersebut. Demikian pula dengan pohon (misalnya pohon enau atau kawung) menghalangi seseorang untuk menebang pohon tersebut. Dalam hal ini berlaku asumsi fungsi manifes dan laten dari adanya sesajen tersebut. Namun, kecenderungan seseorang melihat dengan adanya sesajen tersebut akan menghindari terjadinya penebangan pohon.

Masyarakat Kampung Banceuy juga mengenal hari baik. Pada hari tersebut masyarakat dapat melakukan pekerjaannya. Dalam proses penanaman padi juga dikenal hari yang baik, kapan melakukanpenanamandankapanmemetik hasil panen. Secara tidak langsung terjadi pengaturan waktu penanaman. Dengan melihat masyarakat petani di zaman sekarang yang menggunakan pestisida dan pupuk buatan, hal tersebut dapat dikontrol dengan adanya penentuan hari baik tersebut. Tanah juga akan mempunyai waktu untuk memperbaiki unsur hara yang terkandung di dalamnya. Hal ini juga dapat mengendalikan penggunaan pestisida dan pupuk buatan secara berlebihan.
Dalam falsafah masyarakat setempat dikenal pitutur luhur atau katakata luhur atau bisa juga diartikan katakata bijak. Bagi masyarakat Banceuy, pitutur luhur diperoleh dari leluhur mereka yang mengajarkan nilai-nilai kehidupan tentang bagaimana bersikap sesama manusia maupun perlakuan terhadap alam.

Dalam hubungannya dengan integrasi masyarakat, pitutur luhur yang selalu diperkenalkan oleh sesepuh adat dapat diartikan kerukunan menumbuhkan kekuatan, perpecahan menumbuhkan kerusakan. Pitutur luhur juga menganjurkan kita untuk hidup rukun, dalam arti masyarakat yang terintegrasi.

Ajaran warisan para karuhun juga mengajarkan mereka agar selalu bersikap serasi dengan alam. Kata-kata sesepuh adat ini mengajarkan tentang bagaimana mereka harus mengendalikan diri untuk tidak berbuat semena-mena kepada alam maupun kepada sesama manusia. Mengajarkan masyarakatnya tentang bagaimana mengelola nafsu, mengendalikan nafsu, dan bukan dikendalikan oleh nafsu. Tidak berbuat semena-mena kepada orang lain berarti juga tidak berbuat semena-mena terhadap alam. Jika berbuat semenamena, kerusakan alam karena ulah manusia demi kepentingan pribadi akan berdampak pula pada orang lain.

Sesaji dengan asap dupa mengepul ke udara atau ke langit. dapat diartikan bahwa bumi adalah simbol ibu yang memberikan kesuburan tanah sebagai tempat kegiatan pertanian. Langit adalah simbol bapak yang memberikan keberkahan lewat hujan. Ajaran ini mengajarkankitabagaimanamenyayangi, melindungi, dan menghormati bumi beserta langit sebagaimana kita 
melakukannya kepada kedua orang tua. Jika kita merusak bumi, maka langit pun akan ikut marah. Seperti halnya jika kita berbuat tidak baik kepada ibu, maka bapak pun akan marah, demikian pula sebaliknya. Sebagai contoh adanya perusakan hutan. Hutan merupakan penopang keseimbangan ekosistem. Jika dirusak, maka ekosistem akan kacau dan iklim menjadi tidak menentu. Akibatnya langit menunjukkan kemarahannya dengan fenomena seperti badai, curah hujan tinggi, dan lain-lain.

Ajaran tentang asal-usul manusia yang terdiri atas berbagai unsur, bertolak pada filsafat bumi, air, api, angin, dan awan. Filsafat ini mencerminkan pada filsafat asta brata (delapan elemen dasar) yang terdiri atas delapan elemen unsur alam. Dalam perkembangannya asta brata tidak diajarkan hanya kepada putra mahkota kerajaan, tetapi juga kepada masyarakat luas. Delapan elemen tersebut merupakan elemen yang saling berkaitan satu sama lain dan memiliki pengaruh terhadap kelangsungan hidup manusia.

Terlepas benar atau tidaknya dari ajaran ini, sebagaimana sifat sosiologi yang tidak memandang benar atau salah, tapi lebih menekankan apa yang terjadi dan diajarkan lewat pitutur luhur melalui konsep mitologi.

\section{b. Ritual dan Pelestarian Alam}

Ritual merupakan bagian dari kepercayaan. Di masyarakat Banceuy terdapat ritual yang berhubungan langsung dengan alam. Melihat dari keberadaan mitos yang telah dijelaskan di atas, para penunggu lapisan bumi sebagaimana yang mereka yakini, yaitu roh-roh halus menempati gunung, hutan, dan lautan sebagai tempat tinggal mereka. Ritual diadakan oleh masyarakat setempat sebagai bentuk penghormatan kepada roh-roh sebagai penunggu gunung, hutan, dan dunia air. Bentuk dari ritual tersebut sangat beragam. Mulai dari penghormatan agar roh-roh tersebut tidak menggangu masyarakat, sampai pada penghormatan sebagai bentuk rasa syukur karena telah melimpahkan rejeki.

Ritual-ritual yang dilakukan masyarakat Jawa tidak lepas dari pandangan masyarakat terhadap alam. Dalam upacara selamatan, mereka meminta keberkahan terhadap roh-roh penunggu, lelembut (roh karuhun), jin, dan sebagainya yang menunggu tempat tertentu. Menurut kepercayaan mereka, keberadaan makhluk halus tersebut dapat mendatangkan keberkahan dan keselamatan. Namun jika manusia merusak tempat tinggal mereka, maka akan terjadi malapetaka.

Ritual Ruwat Bumi adalah sebagai wujud dari rasa syukur kepada Tuhan atas rahmat yang diberikan. Ritual tersebut merupakan sebuah nilai yang secara tidak langsung mengajarkan masyarakat akan pentingnya menjaga alam,

Para wisatawan yang mengunjugi tempat wisata Curug Bentang sering melakukan ritual tertentu melalui sesepuh adat setempat. Sebelum memasuki tempat tersebut, mereka memohon keselamatan, sebagai bentuk penghormatan kepada roh penunggu tempat tersebut untuk tidak mengganggu. Secara tersirat ritual tersebut memaksa para wisatawan atau para peziarah untuk tidak melakukan perusakan ketika mengujungi tempat tersebut.

Globalisasi mendatangkan akibat yaitu mudahnya nilai-nilai asing masuk ke dalam suatu negara atau wilayah. Indonesia sebagai negara dunia ketiga tidak lepas dari pengaruh 
asing. Dalam kehidupan kita seharihari banyak kita temukan unsur-unsur asing yang masuk ke dalam masyarakat Indonesia. Dari sisi pola hidup misalnya. Konsumerisme menjamur hampir di setiap lapisan masyarakat. Sikap liberal juga berkembang seiring perkembangan zaman.

Kita semestinya menyikapi globalisasi dengan sikap bijak, bukan berarti tidak setuju dengan adanya globalisasi. Namun yang harus dicermati adalah sikap kita dalam menyambut globalisasi. Hendaknya dalam menghadapi globalisasi dengan tetap berpegang pada nilai-nilai luhur yang diwariskan kepada kita.

Nasib kearifan lokal terus terancam oleh globalisasi. Perlahanlahan namun secara pasti kearifan lokal mulai tergerus oleh perkembangan zaman. Disadari atau tidak, masyarakat Jawa sudah mulai meninggalkan ritualritual yang berhubungan dengan alam, melupakan pitutur luhur atau kata-kata bijak, dan menganggap mitos hanya seuatu kebohongan.

Tidak hanya globalisasi, nilai-nilai masyarakat Barat (westernisasi) pun turut mengancam kearifan lokal. Bisa kita lihat bagaimana generasi muda saat ini meniru pola-pola hidup yang condong ke negara-negara Barat. Dari hal yang sederhana seperti musik, misalnya. Hanya sedikit dari generasi muda yang tahu akan musik tradisional dan hanya segelintir yang mampu memainkan musik tradisional.

Perlu kita ketahui kearifan lokal memainkan peran yang sangat penting dalam turut serta mengatur masyarakat karena di dalamnya melekat nilai-nilai yang sudah mendarah daging. Setidaknya diperlukan sebuah usaha untuk menjamin kearifan lokal agar tetap bertahan di tengah-tengah derasnya globalisasi dan westernisasi.

Di sisa-sisa tenaga kearifan lokal dalam mempertahankan eksistensinya, diperlukan suatu usaha untuk menjaganya agar tetap berkembang dalam masyarakat. Usaha tersebut harus disertai dengan kesadaran akan peranan kearifan lokal yang sangat penting di dalam menghadapi permasalahan.

Pendidikan merupakan media dimana dalam proses pembelajaran ditanamkan nilai-nilai. Dalam memberdayakan kearifan lokal dapat dilakukan dengan mengintegrasikannya pada mata pelajaran tertentu, misalnya muatan lokal. Adapun untuk menanamkan nilai-nilai kelingkungan dapat dilakukan dengan hal yang sama maupun dengan mata pelajaran khusus, seperti pendidikan lingkungan hidup.

Pendidikan tidak hanya di dalam bangku sekolah. Pendidikan yang lebih penting adalah pendidikan sejak dini yang dimulai dari keluarga dengan memperkenalkan kearifan lokal dan menanamkan peduli lingkungan kepada anggota keluarga.

\section{PENUTUP}

Menjaga keseimbangan antara manusia, lingkungan alam fisik, dan lingkungan transendental, sampai sejauh ini masih merupakan nilai falsafah hidup masyarakat Kampung Banceuy yang secara sadar masih sangat kuat berakar dalam pola hidup mereka sehari-hari. Nilai tersebut tidak terlepas dari sumber acuan seluruh gerak langkah mereka dalam mengarungi hidup, yaitu sistem kepercayaan mereka yang senantiasa menjaga hubungan dengan ajaran nenek moyang mereka. Implementasi nilai- 
nilai tersebut membentuk sikap hidup dalam hal pengelolaan lingkungan alam fisik secara arif, yang ditopang dengan kekuatan tradisi yang secara moral dan spiritual mampu mempersatukan dan mengendalikan perilaku masyarakat.

Meskipun masyarakat Kampung Banceuy merupakan masyarakat pedesaan yang sederhana dan tradisional, namun mereka tetap terus berupaya meningkatkan kualitas hidup mereka. $\mathrm{Hal}$ ini dapat disaksikan dari lingkungan alam mereka yang asri. Penataan rumahrumah yang teratur serta kondisi rumah mereka yang sehat dan bersih, serta bangunan rumah mereka yang pada umumnya merupakan rumah permanen. Dalam melaksanakan tradisi, mereka menggunakan bahan-bahan alami seperti bambu, kayu, daun-daunan, serta bahan lainnya. Penggunaan bahan-bahan alam memberikan kesadaran pada pola hidup yang berusaha memanfaatkan sekaligus menjaga lingkungan, agar kebutuhan mereka terhadap bahan-bahan alam terus dapat terjaga dan terpenuhi. Kemudian tidak mengeksploitasi bahan-bahan alam tersebut dengan semena-mena. Kondisi demikian, sampai sejauh ini dapat mereka pertahankan dan cukup menunjang kebutuhan hidup mereka. Sampai kapan kondisi ini dapat mereka pertahankan? Akankah alam sekitar mereka terusmenerus menunjang kebutunan hidup mereka?

Untukmenjawabsemuapertanyaan ini tentunya mereka sendiri yang paling tahu jawabannya. Sejauh ini, mereka tetap berjalan mengikuti alur tradisional yang telah mereka jalani bertahun-tahun secara turun temurun. Tradisi mereka, baik berupa mitos, pantangan, dan ungkapan- ungkapan yang mereka pahami, mampu bertindak sebagai pengendali seluruh aspek kehidupan mereka.

\section{DAFTAR PUSTAKA}

Adeng, et.al. 1991.

Upacara Tradisional Sedekah

Bumi di Cibarusah-Bekasi. Bandung: Proyek terhadap Eksistensi Lembaga Adat Pemerintah Provinsi Daerah Tingkat I Jawa Barat

Ekadjati, Edi S. 1984.

Masyarakat Sunda dan Kebudayaan. Jakarta: Girimukti Pusaka.

Hidayah, Zulyani. 2006.

Metodologi Penelitian "Kepercayaan" Masyarakat. Jakarta: Makalah dalam Penataran Tenaga Teknis Pamong Budaya Sprirtual. 1970.

Manusia dan Kebudayaan Indonesia. Jakarta: Jembatan.

Koentjaraningrat. 1971.

Beberapa Pokok Antropologi

Sosial. Jakarta: Dian Rakyat. 1989.

"Metode Wawancara", dalam Metode-Metode Penelitian Masyarakat. Jakarta: PT Gramedia. 
Nugroho, E. 2000.

Pendidikan, Kebudayaan, dan Masyarakat Madani Indonesia.

Bandung: Remaja Rosdakarya.

Prawirasoeganda, R. Akip. 1982.

Upacara Adat di Pasundan.

Bandung: Sumur Bandung.

Suyitno, Anan. et. al. 1991.

Bunga Rampai Jawa Barat.

Bandung: Yayasan Wahana Citra

Nusantara. 